\title{
A DIVULGAÇÃO DA CIÊNCIA SOBRE OS ANIMAIS NÃO HUMANOS: O CASO DOS EXPERIMENTOS CIENTÍFICOS
}

\author{
VERÔNICA FRANCIELE SEIDEL ${ }^{1}$, \\ CHARLIES UILIAN DE CAMPOS SILVA ${ }^{2}$
}

Universidade Federal do Rio Grande do Sul, Programa de Pós-Graduação em Letras Av. Bento Gonçalves, 9500 - 91509-900 - Porto Alegre - RS - Brasil

veronicaseidel@gmail.com, uiliancampos@gmail.com

\begin{abstract}
Resumo. Como a análise dos fenômenos linguísticos auxilia a compreender os posicionamentos ideológicos que sustentam os discursos, pretendemos entender como a experimentação laboratorial em animais não humanos é apresentada pelo discurso científico. Para isso, analisamos um artigo científico e um artigo de divulgação científica, utilizando como categorias de análise a noção de gênero do discurso. Percebemos, nos discursos analisados, a perspectiva de que o emprego de animais é imprescindivel ao progresso da ciência, de modo que toda atividade contrária à realização de tal prática é vista como radical e prejudicial ao desenvolvimento científico. Observamos, ainda, que o discurso de divulgação científica referenda o status quo do modo de produção científico.
\end{abstract}

Palavras-chave: experimentação científica; língua; ideologia; animais não humanos.

\begin{abstract}
As the analysis of language helps to understand the ideological positions that support the discourses, we aim to understand how laboratory experimentation in nonhuman animals is presented by scientific genre. For this, we analyzed a scientific article and a scientific divulgation article, using as categories of analysis the notion genre discourse. We realize in the analyzed texts the perspective that the use of animals is essential to the progress of science, so that any activity contrary to the realization of this practice is seen as radical and harmful to the scientific development. From this, we observed that the scientific divulgation discourse endorses the status quo of scientific production.
\end{abstract}

Keywords: scientific experimentation; language; ideology; non-human animals.

\footnotetext{
${ }^{1}$ Mestre em Letras, com ênfase em Teorias do Texto e do Discurso, pela Universidade Federal do Rio Grande do Sul (UFRGS).

${ }^{2}$ Doutorando em Letras pela Universidade Federal do Rio Grande do Sul. Professor EBTT DE do Instituto Federal de Educação, Ciência e Tecnologia do Rio Grande do Sul (IFRS).
} 


\section{INTRODUÇÃO}

Nenhum fenômeno da natureza tem significado em si mesmo. É justamente por meio da discursivização que algum significado será atribuído a este ou àquele fato. Podemos dizer, desse modo, com base em Bakhtin (2010), que um discurso é sempre motivado por um reflexo do mundo objetivo, isto é, do mundo dos objetos, na consciência de alguém. Tal reflexo será expresso por esse alguém por meio da língua, de modo que todo discurso sempre será dotado de determinado valor, demonstrando certo posicionamento por parte daquele que o enuncia.

Muito embora as discussões acerca da imparcialidade de alguns discursos tenham avançado consideravelmente nos últimos anos, ainda se confere uma posição de destaque aos discursos científicos, como se estes fossem detentores de uma verdade única e insubstituível. Quando consideramos, de um ponto de vista dialógico da língua, que a verdade, o belo ou o justo não se encontram no objeto em si, mas refletem noções construídas a partir do discurso sobre a realidade material, percebemos que o conhecimento científico não é neutro.

No campo das Ciências Biológicas, por exemplo, é perceptível a coexistência de dois discursos que, embora imparciais, demonstram uma tensão de valores, ou seja, são estruturados a partir de eixos valorativos diferentes. Enquanto um deles afirma a igualdade em termos evolutivos das espécies, outro, embora reconheça tal igualdade, sustenta uma posição de supremacia para os seres humanos em detrimento dos demais seres vivos. Supremacia essa que permite desde o uso de animais em experimentos até a sua criação para o consumo alimentar humano.

Tais discursos refletem e refratam as relações entre os homens, conforme explicita Bakhtin (2010), mas também as relações entre os homens e outros seres vivos, pressupondo um sistema aceito no âmbito da comunidade científica, isto é, tomando determinado paradigma como verdadeiro, que, no caso das Ciências Biológicas, consiste em uma igualdade evolutiva entre as espécies. Essa igualdade se deve ao fato de que o objetivo primevo das espécies é se adaptar ao meio ambiente a fim de se reproduzir e, com isso, passar seus genes às próximas gerações (DARWIN, 2003; DAWKINS, 1979). Desse modo, todas as espécies, embora possam ser mais complexas ou mais derivadas, por terem passado por mais modificações estruturais com o passar do tempo, apresentam o mesmo grau evolutivo, já que todas, de um modo ou de outro, estão adaptadas ao meio em que vivem. Logo, do ponto de vista evolutivo, os seres humanos não seriam superiores ou mais evoluídos que as demais espécies e, consequentemente, não poderiam fazer uso destas conforme ocorre em nossa sociedade, pelo menos não segundo esse pressuposto.

Tendo isso em vista, pretendemos analisar, neste estudo, o modo como o discurso de divulgação científica e o discurso científico percebem e representam os animais não humanos na prática da experimentação laboratorial. Para isso, analisamos um artigo científico e um artigo de divulgação científica acerca da experimentação científica em animais, utilizando como categorias de análise do artigo científico a noção de gênero do discurso. 


\section{GÊNERO DE DISCURSO: CONCEITO E IMPLICAÇÕES}

Para os integrantes do Círculo de Bakhtin, podemos afirmar que a noção de gênero do discurso é fundamental aos estudos da língua, já que a utilização da língua pelos falantes sempre ocorre com base em tipos relativamente estáveis de enunciados, ou seja, de gêneros do discurso. Isso ocorre uma vez que a língua é aprendida por meio de enunciados concretos proferidos por aqueles que nos rodeiam em situações reais de comunicação discursiva, de modo que aprender a interagir pela fala consiste em saber construir enunciados na forma de determinado gênero, tendo em vista as relações histórico-sociais estabelecidas em cada contexto de produção.

Assim, os tipos de enunciados estão diretamente relacionados ao campo da atividade humana em que foram originados, refletindo, portanto, as condições específicas de cada campo (hierarquização das relações sociais vigentes, momento histórico-cultural da sociedade), bem como suas finalidades. Como o uso da língua está presente em todas as áreas da atividade humana, a palavra, embora sirva igualmente a todas elas, faz com que cada uma delas entenda a realidade com base em suas próprias formas de percepção do mundo, alterando e influenciado esse meio também de uma forma particular. Desse modo, cada gênero do discurso é voltado a determinados aspectos da realidade, sendo capaz, consequentemente, de comunicar certas noções acerca das coisas e não outras, já que possui certos princípios de seleção e determinadas maneiras de compreensão dessa realidade. Assim, é possível afirmar que a consciência humana (formada justamente a partir dos embates que a palavra trava nos diferentes campos de produção) possui uma série de gêneros interiores que servem para ver e compreender a realidade, o que faz dos gêneros um conjunto de meios de orientação coletiva na realidade.

Um falante, ao construir seu enunciado, sempre leva em conta, assim, tudo aquilo que já foi dito sobre o objeto ou acontecimento em questão e tudo aquilo que ainda será dito, estabelecendo, desse modo, uma relação de diálogo com outros enunciados anteriores pertencentes ao mesmo gênero e suscitando em seu ouvinte, aquele a quem o enunciado se destina, uma resposta, ou seja, uma posição ativa frente àquilo que foi dito. Assim sendo, um enunciado, além de suscitar uma resposta, é ele mesmo uma resposta a outros enunciados precedentes sobre o mesmo tema.

Como as relações sociais ocorrem em grupos, os quais originam a comunicação e são por ela originados, as formas de comunicação são determinadas pelas relações de produção e pela estrutura sócio-política desses grupos. Desse modo, uma mudança estilística, semântica ou composicional nos gêneros reflete alterações que ocorrem na vida social, fazendo do gênero um importante meio para compreender a sociedade.

Então, como todos os gêneros consistem, na verdade, em pontos de vista específicos sobre o mundo, isto é, em determinadas perspectivas sobre certos objetos, e, uma vez que determinadas formas de enunciados estão ligadas a certas formas da realidade que estes auxiliam a compreender, pretendemos o modo de funcionamento do gênero de divulgação científica e do gênero científico, respondendo à seguinte questão: de que modo tais gêneros percebem e representam os animais não humanos na prática da experimentação científica? 


\section{COMO O HUMANO PERCEBE O NÃO HUMANO: O USO DE COBAIAS}

O primeiro artigo analisado foi publicado em 2002 na Revista Bioética e versa acerca do uso de animais em pesquisas. Essa revista, conforme consta em sua página eletrônica, é uma publicação científica quadrimestral com tiragem de 10 mil exemplares distribuídos gratuitamente.

Os enunciadores desse artigo voltam-se inicialmente ao período do nazismo, remontando ao fato de Hitler ter proibido, após assumir o poder, esse tipo de experimentação. Em seguida, vem a seguinte passagem.

Atualmente se sabe que durante a Segunda Guerra Mundial os nazistas utilizaram seres humanos - sem seu consentimento - como objeto de experimentação, sem dar-lhes a consideração que animais recebiam em laboratórios científicos e hospitais veterinários. Em 1925, Hitler afirmou: "Eu aprendi a desprezar o ser humano do fundo de minha alma". E, em 1926, afirmou também: "Quanto mais eu conheço a espécie humana, mais eu gosto do meu cachorro". Nestas palavras está o ponto crucial das questões éticas relativas ao uso de animais e seres humanos como objeto de experimentações científicas. As questões são: pode alguém amar mais a um animal que a um ser humano? Pode alguém amar mais a doença que a saúde? Pode alguém amar mais a ignorância que o conhecimento do corpo? (RAYMUNDO; GOLDIM, 2002, p. 32-33)

Nesse recorte, é possível perceber que os enunciadores remontam ao período do nazismo para estabelecer um contraponto com a posição adotada no artigo analisado. No período nazista, a ciência praticada partia do conceito de eugenia, que visava a obter uma raça pura e superior, destituída de todos aqueles que pudessem carregar características genéticas inferiores, como deficientes físicos, por exemplo. Tal concepção levou à esterilização forçada de inúmeros indivíduos e ao massacre coletivo de muitos outros, com o intuito de "melhorar a humanidade" por meio do cruzamento seletivo (GUERRA, 2006). Atualmente, o paradigma da eugenia foi negado via desconstrução da ideia de raça, por exemplo. Ao citar Hitler e o nazismo, os enunciadores indicam que a concepção de ciência a que se filiam é outra: uma concepção que não crê na existência de uma raça pura nem na possibilidade de que alguns seres humanos serem superiores a outros.

Ressaltamos, entretanto, que essa menção à Alemanha nazista acaba colocando em voga diversas outras questões além desse posicionamento ideológico. Primeiramente, nesse recorte, aparece o fato de os nazistas terem usado seres humanos em experimentações, fato que não é exclusivo da Alemanha nazista. Como se sabe hoje, nos Estados Unidos, por exemplo, um grupo de 400 pessoas com sífilis foram submetidas a testes sem consentimento; o mesmo ocorreu na União Soviética, quando os russos testavam veneno nos prisioneiros inimigos de guerra; assim como no Japão, tanto em guerras civis quanto na Segunda Guerra Mundial, em que procedimentos como dissecação de pessoas vivas e amputação de membros eram realizados (KOTTOW, 2008). Percebemos, então, que a experimentação em pessoas sem seu consentimento não era tão incomum assim. Mas quais as consequências de escolher justamente o exemplo do nazismo para ser citado e ignorar todos os outros casos de experimentação em humanos? O nazismo é amplamente malvisto, de modo que sua evocação causa aversão e repulsa na maioria das pessoas. Tem-se aqui um primeiro argumento implícito utilizado 
pelos enunciadores para a aceitação da experimentação em animais não humanos ${ }^{3}$ : onde esses animais são poupados, humanos são testados. Logo, conforme os enunciadores, o amor pelos animais levaria a um sofrimento dos seres humanos, como aconteceu na Alemanha nazista, em que Hitler afirmava desprezar o ser humano e amar o seu cachorro.

Retomemos o recorte anterior para que seja possível dar continuidade à análise.

Atualmente se sabe que durante a Segunda Guerra Mundial os nazistas utilizaram seres humanos - sem seu consentimento - como objeto de experimentação, sem dar-lhes a consideração que animais recebiam em laboratórios científicos e hospitais veterinários. Em 1925, Hitler afirmou: "Eu aprendi a desprezar o ser humano do fundo de minha alma". E, em 1926, afirmou também: "Quanto mais eu conheço a espécie humana, mais eu gosto do meu cachorro". Nestas palavras está o ponto crucial das questões éticas relativas ao uso de animais e seres humanos como objeto de experimentações científicas. As questões são: pode alguém amar mais a um animal que a um ser humano? Pode alguém amar mais a doença que a saúde? Pode alguém amar mais a ignorância que o conhecimento do corpo? (RAYMUNDO; GOLDIM, 2002, p. 32-33)

Nesse recorte, os enunciadores afirmam que os humanos testados na Alemanha de Hitler não recebiam a mesma consideração que os animais não humanos recebiam em laboratórios científicos e hospitais veterinários. Contudo, o modo como animais não humanos vivem em laboratório, isto é, a que condições são submetidos, ainda não havia sido apresentado no artigo para que os enunciadores pudessem realizar uma comparação entre o modo de tratar os animais e o modo de tratar os seres humanos. Nesse sentido, afirmam que os nazistas negavam aos humanos as benesses que os outros animais recebiam em experimentos, o que se torna, pelo menos, difícil de apreender, uma vez que não sabemos, via artigo, qual seria o tratamento dispensado aos animais não humanos em outras partes do mundo para compará-lo ao tratamento concedido aos humanos durante o regime nazista.

Um último ponto a ser ressaltado aqui consiste no chamamento de uma questão de ordem sentimental: "pode alguém amar mais a um animal que a um ser humano?" (RAYMUNDO; GOLDIM, 2002, p. 33). Tal inserção é curiosa na medida em que um artigo que tem a pretensão de se basear em fatos de ordem lógica, como ainda é o caso da maioria dos discursos das ciências naturais e exatas, que visa a discutir a ética na experimentação animal, traz à tona um questionamento acerca da capacidade de amar de alguém. Ademais, uma pergunta como essa para fazer o texto avançar minimamente em seus propósitos precisaria, ao menos, estar embasada em reflexões psicanalíticas se quisesse demonstrar ao leitor de que modo a capacidade de amar tem relação com o tema abordado. Ressaltamos, ainda, que tal questão parece pressupor que existe um modo certo de amar (amar mais os humanos) e um modo errado (amar mais os não humanos). Diante da referência à barbárie cometida no nazismo, torna-se plausível a hipótese de que a não utilização de animais não humanos em experimentos remete à anormalidade (no sentido de patológico) dos acontecimentos, seja pela alusão ao nazismo, seja pelo questionamento da capacidade de "amar certo".

\footnotetext{
${ }^{3}$ Utilizaremos a expressão animais não humanos para marcar nosso posicionamento em relação ao tema, embora os enunciadores do artigo analisado não façam uso dessa expressão. Nossa escolha deve-se ao fato de que os seres humanos também são animais e a uma tentativa de fugir do paradigma especista. Ressaltamos, ainda, que tal termo é comum e amplamente utilizado nas discussões acadêmicas e ativistas sobre o tema.
} 
Após ter evocado os experimentos científicos realizados com humanos no período do nazismo, os enunciadores tratam do "ressurgimento do debate sobre a utilização de animais em pesquisas e em outras atividades", trazendo à tona pensadores-chave para compreender esse debate e algumas declarações criadas para regulamentar o tema. Afirmam, então:

Durante a década de 80, o movimento para eliminar o uso de animais em pesquisas biomédicas cresceu assustadoramente [...]. Alguns grupos radicais na defesa dos direitos dos animais praticaram atentados contra laboratórios, biotérios, instalações universitárias [...] tais grupos protagonizaram mais de 29 ataques a instituições americanas de pesquisa, roubando mais de 2.000 animais. (RAYMUNDO; GOLDIM, 2002, p. 34)

Nesse recorte, os enunciadores demonstram certo posicionamento ideológico ao optarem pela utilização de alguns termos, que denotam um julgamento de valor explícito acerca do movimento contra a utilização de animais não humanos em experimentos. $\mathrm{O}$ uso do termo "grupos radicais", por exemplo, indica que os enunciadores percebem as iniciativas de grupos engajados na libertação de animais utilizados em laboratórios como algo extremado que envolve, inclusive, o roubo de animais.

Sob nossa perspectiva, esse posicionamento revela uma visão que considera os animais não humanos um bem ou um objeto que pertence a alguém, pois apenas nessa concepção poderiam ser roubados e não raptados ou levados, por exemplo. Nesse sentido, até agora, o artigo é construído por meio da apresentação de uma síntese do que é desenvolvido em todo o artigo, evocando o período nazista e o modo como os experimentos científicos ocorriam nessa época e apresentando algumas atividades de grupos contra a utilização de animais em experimentos.

A seguir, os enunciadores mencionam que

Estas ações atingiram tal magnitude que a Associação Mundial de Medicina publicou uma declaração específica sobre o uso de animais em pesquisas biomédicas, incluindo a necessidade de reunir esforços para proteger pesquisadores e seus familiares. (RAYMUNDO; GOLDIM, 2002, p. 34)

Esse recorte indica, então, que as ações que os enunciadores denominaram de radicais levaram à implementação de esforços por parte da Associação Mundial de Medicina para evitar os danos causados pelos grupos radicais. Tem-se, assim, mais um elemento para a progressão temática do discurso em questão: a contrapartida de uma associação de medicina aos atos daqueles que são contra a experimentação. Ao evocar tal associação, os enunciadores colocam-se a favor dos testes científicos em animais, corroborando o posicionamento demonstrado no recorte anterior: de que aqueles que roubam animais de laboratórios causam danos tanto às pesquisas em si quanto aos pesquisadores e seus familiares.

Contudo, sob nosso ponto de vista, o recorte em questão revela o que poderíamos denominar de inversão de papéis: os animais não humanos são utilizados em experimentos, mas quem precisa de proteção são os pesquisadores, isto é, quem faz uso desses animais. Tal proposição é plausível se considerarmos que, em toda a história de manifestos contra o uso de animais não humanos em experimentos, não existem relatos de qualquer injúria causada pelos manifestantes aos pesquisadores. Assim, a afirmação 
em questão, além de deslegitimar os movimentos antiespecistas, realiza uma inversão da necessidade de proteção: a vítima aqui não é o animal submetido a experimento, mas aquele que o submete.

Em seguida, após citar a iniciativa da Associação Mundial de Medicina, os enunciadores dissertam acerca de outras leis e resoluções criadas para regulamentar a utilização de animais não humanos em experimentos. Mencionam que, no Brasil, a Lei de Crimes Ambientais de 1998

estabelece que é crime praticar ato de abuso, maus-tratos, ferir ou mutilar animais silvestres, domésticos ou domesticados, nativos ou exóticos, sob pena de detenção por um período de três meses a um ano e multa. O primeiro parágrafo deste artigo diz que "incorre nas mesmas penas quem realiza experiência dolorosa ou cruel em animal vivo, ainda que para fins didáticos ou científicos, quando existirem recursos alternativos". (BRASIL, 1998 apud RAYMUNDO; GOLDIM, 2002, p. 35)

Nesse recorte, ao evocar a legislação após ter apresentado o imbróglio entre aqueles que são contra os testes (grupos que praticam atentados contra laboratórios) e aqueles que são a favor (Associação Mundial de Medicina, por exemplo), os enunciadores filiam-se ao que prevê a Lei de Crimes Ambientais: que a prática de experimentos, ainda que cruéis ou dolorosos, é permitida caso não existam recursos alternativos. Assim, o discurso de outrem, isto é, da legislação, é trazido ao artigo ora analisado para sinalizar a aceitação de uma prática (a dos testes em animais) que é legal do ponto de vista jurídico, ainda que do ponto de vista ético possa ser discutida.

Diante disso, podemos perceber que a proibição de experimentos dolorosos só ocorre em caso da existência de recursos alternativos. Ou seja, o bem-estar do animal não humano submetido à experimentação só precisa ser respeitado se houver outras formas de efetuar o mesmo teste. Novamente, não há nenhuma consideração sobre a vida desse animal em si, que seja independente da vida dos animais humanos. A existência daquele está condicionada ad eternum à existência deste, de modo que sua vida só será respeitada se ele não for "necessário" para as experiências.

Após discorrer sobre a Lei de Crimes Ambientais, os enunciadores detalham os aspectos éticos envolvidos na experimentação em animais, questão que consiste no objetivo principal do artigo. Nesta seção, é realizado um percurso histórico da temática por meio da citação de inúmeros pensadores que trataram da condição dos animais em nossa sociedade: Michel Montaigne, René Descartes, David Hume, Jeremy Bentham, Claude Bernard, William M.S. Russell, Rex L. Burch, Peter Carruthers, Peter Singer, Albert Schweitzer, Robert Veatch e Tom Regan. Sobre Descartes, os enunciadores do artigo afirmam que talvez as diferenças entre os homens e os animais assinaladas pelo pensador francês

tenham influenciado os cientistas do século XVII a realizarem seus experimentos sem questionar o uso de animais. As considerações deste pensador de que os processos de pensamento e sensibilidade correspondem à alma talvez tenham levado os cientistas da época a pensarem que por serem desprovidos de uma alma "racional" não havia possibilidade dos animais sentirem dor. (RAYMUNDO; GOLDIM, 2002, p. 37) 
Ressaltamos aqui uma questão importante para refletir sobre a temática que surgirá novamente nas proposições dos outros estudiosos citados: a relação entre corpo e alma. Descartes parte do princípio de que, se os animais não humanos não têm alma, logo não podem sentir dor. Lembremos que essa justificativa foi a mesma utilizada pelos portugueses ao colonizarem o Brasil em relação aos índios: não têm alma, portanto podem ser escravizados. Contrapondo os fundamentos da base escravista, o inglês Bentham (1789) afirmou:

os franceses já descobriram que a cor preta da pele não constitui motivo algum pelo qual o ser humano possa ser entregue, sem recuperação, ao capricho do verdugo. Pode chegar o dia em que se reconhecerá que o número de pernas, a pele peluda, ou a extremidade dos sacrum constituem razões igualmente insuficientes para abandonar um ser sensível à mesma sorte. Que outro fator poderia demarcar a linha divisória que distingue os homens de outros animais? Seria a faculdade de raciocinar, ou talvez a de falar? Todavia, um cavalo ou um cão adulto é incomparavelmente mais racional e mais social e educado que um bebê de um dia, ou de uma semana, ou mesmo de um mês. Entretanto, suponhamos que o caso fosse outro: mesmo nessa hipótese, que se demonstraria com isso? O problema não consiste em saber se os animais podem raciocinar; tampouco interessa se falam ou não; o verdadeiro problema é este: podem eles sofrer? (apud RAYMUNDO; GOLDIM, 2002, p. 37)

Ao apresentar ao leitor o percurso histórico dos aspectos éticos ligados à experimentação animal, os enunciadores vão contrapondo diferentes bases argumentativas acerca da temática: trazem pensadores que foram a favor da experimentação e pensadores que foram contrários à realização dos testes em animais. Assim, apresentam primeiramente Descartes, que entendia, segundo os enunciadores, que somente os homens eram sensíveis à dor, e, após, evocam o pensamento de Bentham, que acreditava que os animais eram passíveis de sentir dor.

Aqui Bentham (1789 apud RAYMUNDO; GOLDIM, 2002) propõe uma reflexão interessante: não estariam os animais submetidos hoje às mesmas condições que negros (e índios) foram submetidos anteriormente? Além disso, qual seria a característica que, verdadeiramente, deveria ser levada em conta? Ele responde-nos: a capacidade de sofrer. Os animais não humanos, assim como negros e índios já foram, são vistos como inferiores e, por isso, podem (e devem) servir ao ser humano. Necessário observar, contudo, que essa decisão de quem é ou não inferior advém, curiosamente, daquele que sempre se julga superior. Dessa forma, parece uma luta injusta e eternamente invencível: os parâmetros estabelecidos para analisar a superioridade são aqueles característicos da espécie que tem interesse em dominar outros seres (de sua própria espécie ou não). Stephen Jay Gould, no livro A falsa medida do homem $^{4}$, discorre sobre a validade dos testes de QI realizados antigamente. Quando surgiram, as características biométricas relacionadas ao resultado do teste de QI eram baseados na fisiologia de homens (sexo masculino) brancos, indoeuropeus. Assim, obviamente, todos aqueles de outras etnias apresentavam, como se espera, diferenças, consideradas na época como sinal de inferioridade. Além disso, muitas pessoas submetidas ao teste não dominavam a língua em que este era aplicado ou não sabiam escrever; logo, obtinham pontuação mais baixa. Consequentemente, os diferentes tinham QI menor, resultado falacioso conforme a leitura de Gould.

${ }^{4}$ GOULD, S.J. A falsa medida do homem. São Paulo: Martins Fontes, 1991. 
Os enunciadores mencionam, então, que, a partir das colocações de Bentham, inúmeras questões sobre a experimentação animal podem ser levantadas.

Dentre essas questões pode-se destacar o direito dos homens de utilizar animais como cobaias e a validade da transposição para o ser humano dos resultados encontrados em estudos realizados em animais. (RAYMUNDO; GOLDIM, 2002, p. 37-38)

Ressaltamos, contudo, que o direito dos homens de utilizar animais como cobaias não é colocado em xeque, de fato, no artigo, assim como a validade da transposição dos resultados. Os enunciadores apenas citam essas questões, mas não discutem se esse direito existe ou não e se os resultados obtidos nos testes realizados em animais não humanos podem ser extensíveis aos humanos, como veremos a seguir. Discorre-se sobre a manutenção do bem-estar animal em laboratório, as leis que surgem para esse fim, a premissa de recorrer a cobaias apenas quando não houver métodos alternativos e as características apontadas por outros estudos acerca das diferenças entre animais humanos e não humanos. Mas o direito de utilizar ou não esses animais não é discutido em seu cerne. Poderíamos afirmar, a partir da leitura atenta do texto em questão, que sua base consiste em apresentar um percurso histórico da utilização de animais não humanos em experimentos e não sobre a legitimidade de tal prática.

Continuando a apresentação desse percurso histórico, Raymundo e Goldim afirmam, então, que

provavelmente a partir das idéias de Bentham (1748-1832) aparecem as primeiras ações com relação à proteção aos animais. Em 1822, é instituída a Lei Inglesa Anticrueldade (British Anticruelty Act). Esta regra foi também chamada de Martin Act, em memória de seu intransigente defensor Richard Martin. (2002, p. 38)

Aqui temos dois pontos a serem discutidos: 1) o surgimento de práticas a partir de determinados estudos; e 2) a classificação de um dos defensores da lei como intransigente. Assim como os enunciadores já apontaram no caso de Descartes, afirmando que teria sido a partir de suas ideias que os cientistas realizaram experimentos em animais sem questionar essa conduta, o fazem em relação às proposições de Bentham, demonstrando uma visão binária da influência entre ciência e práxis. Parece que a ciência produz suas reflexões de forma apartada da realidade prática, mas, influencia essa realidade. Os enunciadores não levam em conta que possivelmente a realidade das práticas com animais tenha influenciado esses pensadores a refletirem sobre a questão, em uma via de mão dupla: a ciência influencia a vida e a vida influencia a ciência. O segundo ponto recai sobre o mesmo princípio já discutido aqui - a presença de um julgamento de valor explícito ao utilizar o adjetivo intransigente para designar um dos defensores da lei. Lembramos que esse termo pode caracterizar tanto alguém que não faz concessão, sendo inflexível e intolerante, quanto alguém que é austero e rígido na observância de seus princípios.

Seguindo uma linha temporal de estudos que tangenciam o tema da experimentação, os enunciadores citam a publicação de Charles Darwin, em 1859, da obra A Origem das Espécies, em que o naturalista

estabelece os pressupostos do vínculo existente entre as diferentes espécies animais num único processo evolutivo. Desta forma, a teoria de Darwin possibilitou a extrapolação dos dados obtidos em pesquisas 
com modelos animais para seres humanos, dando um maior respaldo aos cientistas que utilizavam animais em suas pesquisas. Esta é uma relação paradoxal, pois as constatações de Darwin associadas às investigações que já haviam demonstrado semelhanças importantes entre as estruturas e funcionamento do corpo dos seres humanos e de alguns animais permitiram que estes fossem ainda mais utilizados. (RAYMUNDO; GOLDIM, 2002, p. 38)

Nesse recorte, é possível perceber que os enunciadores trazem o pensamento de Darwin por meio de um relato, o que permite maior liberdade no modo de transpor o conteúdo e a forma do discurso de outrem ao artigo. Assim, os enunciadores entendem que as colocações darwinianas teriam proporcionado maior segurança aos pesquisados para extrapolar os resultados obtidos em testes com animais aos humanos, uma vez que haveria semelhanças fisiológicas e estruturais entre as espécies animais (humanos e demais animais).

Precisamos, ressaltar que, embora a obra de Darwin tenha influenciado o pensamento científico da época, revolucionando o modo como o ser humano via a si mesmo, seu pressuposto, contudo, é o de que todas as espécies, e não apenas as espécies animais, apresentam vínculo evolutivo entre si. Esse vínculo pode ser explicado pela seleção natural, uma vez que, conforme Darwin (2003), apenas aqueles seres adaptados ao meio ambiente em que vivem são capazes de sobreviver e de deixar descendentes férteis para a próxima geração, sendo este o objetivo biológico da existência: passar os genes adiante. Como todas as espécies existentes estão adaptadas ao meio em que vivem, de acordo com os pressupostos de Darwin (2003), todas elas são igualmente evoluídas deste ponto de vista, podendo ser algumas estruturalmente mais simples ou mais complexas. Segundo conclusão dos enunciadores do artigo analisado, a descoberta de Darwin teria respaldado a experimentação animal devido à presença de semelhanças e, consequentemente, à possibilidade de transpor os resultados obtidos.

Em seguida, mencionam que essa questão é paradoxal, pois as semelhanças observadas levaram a uma utilização ainda maior dos animais não humanos em experimentos. Não explicam, contudo, o motivo deste paradoxo: aspecto que compreendemos como essencial para entender o debate atual sobre a experimentação laboratorial e os direitos dos animais de maneira geral. A existência de um paradoxo significa que há uma contradição, questão essencial à existência do ser humano sob uma perspectiva materialista, sendo necessário refletir sobre ela. Assim, se a semelhança entre humanos e não humanos levou ao aumento da realização de testes com estes, qual seria a contradição a que os enunciadores se referem, mas não explicitam?

Sob nossa perspectiva, se existem semelhanças, há uma maior probabilidade de que os resultados obtidos em uma espécie possam ser extensíveis à outra. Entretanto, se existem semelhanças, os princípios válidos para uma espécie e para a outra também devem ser os mesmos. Dessa forma, se os seres são similares, eles deveriam ter os mesmos direitos, o que implica que os animais não humanos, assim como os humanos, sentem dor, frio, medo, fome e outras sensações possíveis àqueles com sistema nervoso central; logo, ao serem utilizados como cobaias, estão sendo submetidos a sensações indesejáveis, não tendo seus direitos preservados. Esse é o paradoxo que os enunciadores não explicam: se são semelhantes, podem, pelo menos em teoria ${ }^{5}$, gerar resultados aplicáveis aos humanos; e podem sentir e ter as mesmas sensações.

\footnotetext{
${ }^{5}$ Há inúmeros estudos que demonstram que os resultados obtidos na experimentação em animais não humanos, muitas vezes, não podem ser extensíveis aos humanos, ainda que haja semelhanças genéticas
} 
Após (não) discorrer sobre o paradoxo das implicações da teoria de Darwin, os enunciadores do texto analisado, trazem uma citação de Bernard para justificar "o sacrifício de alguns seres vivos em detrimento de outros" (RAYMUNDO; GOLDIM, 2002, p. 39).

Nós temos o direito de fazer experimentos animais e vivissecção? Eu penso que temos este direito, total e absolutamente. Seria estranho se reconhecêssemos o direito de usar os animais para serviços caseiros, para comida, e proibir o seu uso para a instrução em uma das ciências mais úteis para a humanidade. (1865 apud RAYMUNDO; GOLDIM, 2002, p. 39)

O modo como o discurso de Bernard é apropriado consiste em uma tentativa de justificar o uso de animais não humanos em experimentos com a alegação de que esse uso, menos "nobre" talvez, seja feito em outros campos (como alimentação e transporte). O princípio consiste, assim, em: se esses animais são utilizados para outros fins, também podem ser utilizados para a produção da ciência.

Contudo, ressaltamos que o fato de animais não humanos serem usados para alimentação, por exemplo (o que também não foi questionado, sendo, portanto, complicado transformar este dado na justificativa para outros atos), só reafirma a condição de objeto em que se encontram, explicitando que esse uso ocorre em grande escala na sociedade. É, assim, o mesmo princípio geral: eles são usados em benefício dos humanos, não importando a finalidade. Usa-se, dessa forma, um acontecimento não questionado, mas questionável, para justificar outro acontecimento que também não se quer questionar: teriam os homens esse direito?

Após, os enunciadores citam um modelo criado em 1959 por Russell e Burch, o modelo dos três "Rs" da pesquisa em animais (replace, reduce e refine).

Esta proposta não impede a utilização de modelos animais em experimentação, mas faz uma adequação no sentido de humanizá-la [...]. Ela é claramente precursora dos esforços atuais que visam substituir o uso de modelos animais para a realização de pesquisas científicas por técnicas alternativas, reduzir o número de exemplares utilizados e garantir técnicas que minimizem o sofrimento dos animais. (RAYMUNDO; GOLDIM, 2002, p. 39)

O modo de apropriação do discurso de Russell e Burch por Raymundo e Goldim indica que o modelo dos três " $R$ " seria uma solução à problemática da experimentação animal, pois humanizaria tal prática. Assim, esse modelo conseguiria aliar os testes científicos em animais a uma prática científica mais humana, isto é, menos causadora de sofrimento aos animais utilizados, além de diminuir a quantidade de animais empregados. Percebemos, então, que a apropriação desse discurso serve diretamente aos interesses dos enunciadores do artigo, uma vez que defende a "humanização"6 das práticas envolvendo animais como a solução aos embates de cunho ético, levando à ideologia que irá dominar no texto.

consideradas significativas. Conferir, por exemplo, MARRAS, S. Ratos e homens e o efeito placebo: um reencontro da cultura no caminho da natureza. Campos, Paraná, v. 2, 117-33, 2002.

${ }^{6}$ A tentativa de humanizar as práticas com animais é também conhecida como bem-estarismo. Esta expressão designa medidas que buscam promover o bem-estar dos animais quando usados pelos humanos. Trata-se, portanto, de uma posição ideológica que intenta legitimar o emprego de animais não humanos para beneficiar os humanos, revestindo-o de um caráter humanitário. 
Esse modelo busca, conforme explicam os enunciadores, humanizar a experimentação com animais não humanos, lembrando que o verbo tem a acepção de conceder condição humana ou tornar tolerável/amenizar. Uma vez que a experimentação laboratorial com humanos só é permitida atualmente se houver consenso destes, dentre outros quesitos que devem, obrigatoriamente, ser respeitados, o sentido do termo aqui parece ser o de amenizar. Percebamos, contudo, que este é um verbo que exige complemento, sendo preciso responder à seguinte questão: amenizar o que? O sofrimento. Isso pode ser confirmado se analisarmos o terceiro " $R$ " presente no recorte supracitado refine, ou seja, "garantir técnicas que minimizem o sofrimento dos animais" (RAYMUNDO; GOLDIM, 2002, p. 39). Tal concepção admite que a experimentação em animais não humanos causa sofrimento a estes.

Em seguida, os enunciadores apresentam a reflexão de um dos principais pensadores contemporâneos sobre a condição dos animais na sociedade: Peter Singer. Este defende a igualdade entre os seres humanos e os outros animais com base no princípio da igual consideração de interesses. Sob a perspectiva de Singer, uma vez que aceitamos que os outros membros da nossa espécie têm os mesmos direitos que nós, devemos estender essa forma de raciocínio a todos os animais.

A capacidade de sofrer ou de desfrutar coisas é a característica que confere a um ser, seja ele humano ou animal, o direito à igual consideração. Se um ser sofre, não pode haver nenhuma justificativa de ordem moral para nos recusarmos a levar esse sofrimento em consideração. (SINGER, 1994, p. 67, apud RAYMUNDO; GOLDIM, 2002, p. 40)

Ao encontro dessa percepção, os enunciadores citam Tom Regan, que entende que todos aqueles que são sujeitos de uma vida - têm crenças e desejos, percepção, memória, senso de futuro (incluindo seu próprio futuro), sentimentos de prazer e dor, habilidade para iniciar uma ação perseguindo seus desejos e objetivos etc. - possuem o mesmo valor intrínseco, merecendo, portanto, os mesmos direitos, não podendo ser tratados como meros objetos.

Após tais considerações, Raymundo e Goldim (2002) afirmam que

as pesquisas com animais são realizadas há milhares de anos e é inegável que trazem benefício para o desenvolvimento da ciência e de novas tecnologias, principalmente na área da saúde. A partir das considerações apresentadas neste artigo, conclui-se que o uso de animais em atividades científicas deve ser substituído, sempre que possível, por outras alternativas. (RAYMUNDO; GOLDIM, 2002, p. 41)

Diante da análise dos recortes apresentados, é possível notar que a posição ideológica dos enunciadores é de que as pesquisas com animais não humanos, embora devam ser substituídas por métodos alternativos quando possível, precisam ser realizadas por dois motivos: 1) porque sempre foi assim; e 2) porque trazem benefícios para a ciência e a tecnologia. Podemos perceber, então, que o tema da experimentação em animais não humanos é visto como complexo, uma vez que os enunciadores apresentam, por exemplo, pensadores com visões opostas sobre a mesma temática. Apesar de tal complexidade, a utilização de animais é entendida como necessária ao progresso da ciência. 
Já o segundo artigo selecionado para análise, publicado na revista Ciência Hoje em 2006, intitula-se Experimentação com animais: uma polêmica sobre o trabalho científico $^{7}$. A Ciência Hoje foi criada em 1982 pela Sociedade Brasileira para o Progresso da Ciência (SBPC), sendo a revista mais antiga de divulgação científica em circulação no Brasil. Com uma tiragem de aproximadamente 300 mil exemplares por mês, publica artigos sobre diversas áreas da ciência, como biologia, química e matemática.

O artigo de divulgação científica, denominado de discurso-alvo, trata, assim, como o artigo científico anteriormente discutido, do tema da experimentação científica em animais. Esse artigo inicia com um pequeno resumo do texto, embora o subtítulo Resumo não apareça no artigo, situado à esquerda e em fonte maior que o restante do texto, ao lado de uma imagem, sem legenda, de um coelho (com uma mancha amarelada na cabeça, ilustrando alguma etapa de um dos testes científicos efetuados) que ocupa dois terços da página inicial da publicação. O resumo afirma o seguinte.

Nos últimos tempos, os meios de comunicação brasileiros divulgaram notícias sobre tentativas de proibir sumariamente o uso de animais em pesquisas científicas. A questão da experimentação com animais é complexa e os cientistas - ao contrário do que alguns pensam - não estão alheios a ela. Organizações científicas internacionais e instituições públicas ou privadas do setor, em diferentes países, debatem o tema e buscam soluções para reduzir o número de animais utilizados, planejar as pesquisas de forma a lhes causar menor sofrimento e substituí-los sempre que for possível. O emprego de animais em estudos científicos ainda é indispensável em muitos casos, mas isso é feito hoje de acordo com normas éticas internacionalmente aceitas, e os próprios cientistas investigam novos métodos que permitam minimizar ou eliminar essa necessidade. (ALVES; COLLI, 2006, p. 24)

A asserção presente nesse recorte de que "os meios de comunicação brasileiros divulgaram notícias sobre tentativas de proibir sumariamente o uso de animais em pesquisas científicas" (ALVES; COLLI, 2006, p. 24) revela duas características que se fazem presentes no decorrer do artigo: um julgamento de valor sobre a experimentação em animais e uma referência ao contexto específico do Brasil no que diz respeito à experimentação animal, característica esta que é menos evidente no artigo científico analisado anteriormente (já que o tema é tratado de forma mais global).

Nesse mesmo recorte, os enunciadores mencionam que o tema da experimentação animal é complexo e que, "ao contrário do que alguns pensam" (ALVES; COLLI, 2006, p. 24), os cientistas não estão alheios a tal complexidade. Iniciam, assim, uma defesa da complexidade do tema, avisando os leitores de que não se trata de uma questão facilmente resolvível e que os cientistas, responsáveis pela experimentação realizada, sabem dessa complexidade. Isso indica, ainda, que algumas pessoas - contrárias à realização desses testes - acreditam que os cientistas não estão preocupados com a questão, o que não seria verdade uma vez que se buscam "soluções para reduzir o número de animais utilizados, planejar as pesquisas de forma a lhes causar menor sofrimento e substituí-los sempre que for possível" (ALVES; COLLI, 2006, p. 24). Além disso, o "emprego de animais em estudos científicos ainda é indispensável em muitos casos" (ALVES; COLLI, 2006, p. 24), questão que configura a posição que os enunciadores assumem acerca do tema da

\footnotetext{
${ }^{7}$ ALVES, M.J.M.; COLLI, W. Experimentação com animais: uma polêmica sobre o trabalho científico. Ciência Hoje, v. 39, n. 231, 24-29, out. 2006.
} 
experimentação animal: ou seja, ainda que os cientistas estejam preocupados com tal prática e que se tente cada vez mais reduzir o emprego de animais, a realização de testes em animais é necessária.

Após o resumo, os enunciadores apresentam uma estimativa do número de animais não humanos empregados em experimentos atualmente.

Um cálculo aproximado sugere algumas dezenas de milhões por ano, sendo 15 milhões nos Estados Unidos, 11 milhões na Europa, 5 milhões no Japão, 2 milhões no Canadá e menos de 1 milhão na Austrália (no Brasil, o número é desconhecido, mas insignificante diante dos totais mundiais). Pode-se dizer que $80 \%$ dos animais experimentais são roedores - camundongos, ratos e cobaias - criados para essa finalidade, e que outros $10 \%$ são peixes, anfíbios, répteis e pássaros. Um terceiro grupo abrange coelhos, cabras, bois, porcos e, em menor quantidade, cachorros, gatos e algumas espécies de macacos. Eles substituem o ser humano como objeto de experimentação em pesquisas científicas, na preparação e controle de qualidade de medicamentos e no ensino. (ALVES; COLLI, 2006, p. 25)

A asserção presente nesse recorte de que o número de animais testados é "desconhecido, mas insignificante diante dos totais mundiais" (ALVES; COLLI, 2006, p. 25), e a avaliação que se articula à asserção ocupam a função de tranquilizar o leitor quanto à quantidade de animais utilizados em testes, uma vez que, no Brasil, a experimentação afetaria poucos animais, já que o índice não é significativo. Dessa forma, a progressão temática ocorre à medida que o leitor fica sabendo que, além de existirem esforços para a diminuição do número de animais empregados, poucos animais são submetidos a testes se tivermos como parâmetro o índice de animais utilizados no mundo todo.

Ainda nesse recorte, os enunciadores mencionam que " $80 \%$ dos animais experimentais são roedores - camundongos, ratos e cobaias - criados para essa finalidade" (ALVES; COLLI, 2006, p. 25). Diante disso, podemos pensar sobre a distinção realizada entre ratos e camundongos de um lado e cobaias de outro. De um ponto de vista semântico, tal distinção é equivocada, pois tanto ratos quanto camundongos são cobaias (este termo é, portanto, uma hiperonímia para ratos e camundongos). Aqui aparece, ainda, uma justificativa para o uso desses animais: são criados para isso. Essa é a posição política e ética dos enunciadores: os animais utilizados em laboratórios podem ser empregados para esse fim porque foram criados para isso. Observemos, contudo, que tal fato não constitui razão para aceitar a experimentação sem questioná-la. Os enunciadores afirmam, então, ainda no recorte transcrito, que esses animais "substituem o ser humano como objeto de experimentação em pesquisas científicas, na preparação e controle de qualidade de medicamentos e no ensino" (ALVES; COLLI, 2006, p. 25). Tal prerrogativa - de que os animais substituem os humanos em testes - também aparece no artigo científico analisado. Neste, ao citar o nazismo alemão, os enunciadores indicam que inúmeros seres humanos foram submetidos a testes em um contexto ditatorial caracterizado, dentre outras questões, pelo amor de Hitler ao seu cachorro em detrimento da espécie humana: "Quanto mais eu conheço a espécie humana, mais eu gosto do meu cachorro" (RAYMUNDO; GOLDIM, 2002, p. 33).

Posteriormente, após contextualizar o tema, os enunciadores citam dois pensadores que teriam discutido essa questão: Jeremy Bentham e Claude Bernard, 
também citados no artigo científico, afirmando que tal discussão começou no século XVIII.

A utilização dos animais em pesquisas vem sendo discutida desde o século 18. Em 1789, o filósofo inglês Jeremy Bentham (1748-1832), um dos primeiros pensadores a se preocupar com o bem-estar dos animais, já dizia: "A questão não é se os animais podem raciocinar ou falar, mas se podem sofrer." Quase um século depois, em 1865, o fisiologista francês Claude Bernard (1813-1878) defendia o direito de fazer experimentos em animais e vivissecção: "Eu penso que temos esse direito, total e absolutamente. Seria estranho se reconhecêssemos o direito de usar os animais para serviços caseiros e alimentação, mas proibíssemos seu uso para o ensino de uma das ciências mais úteis para a humanidade. Experimentos devem ser feitos tanto no homem quanto nos animais. Os resultados obtidos em animais podem ser todos conclusivos para o homem, quando sabemos como experimentar adequadamente". (ALVES; COLLI, 2006, p. 26)

\title{
Após a menção à Bentham e à Bernard, Alves e Colli afirmam, então, que
}

\begin{abstract}
essas duas observações [de Bentham e Bernard, apresentadas no recorte anterior] definem o ponto principal do problema. O progresso das ciências médicas, biomédicas, biológicas e assemelhadas dependeu e ainda depende da experimentação em animais, e existem numerosos exemplos. Alguns defensores mais radicais dos direitos dos animais argumentam que, como estes são diferentes do ser humano, nada do que se estuda neles ajuda a entender a nossa espécie. Nada mais falso, já que todas as células vivem em conseqüência de um concerto de reações químicas muito semelhantes em todos os organismos - desde os mais simples até o Homo sapiens. (2006, p. 26)
\end{abstract}

Esse recorte auxilia a entender alguns pontos relevantes sobre o modo como os enunciadores percebem o tema do artigo. O progresso da ciência dependeu, como os enunciadores defenderão a seguir, apresentando exemplos de descobertas obtidas a partir da experimentação animal, do uso de animais em testes. Ainda que tais avanços não pudessem ter sido obtidos sem esse uso, inúmeros estudos demonstram que atualmente é possível prescindir da experimentação em animais. Essa possibilidade, entretanto, é negada pelos enunciadores do artigo de divulgação científica ao afirmarem que os defensores mais radicais dos direitos dos animais estão equivocados quando contraargumentam, por exemplo, que as diferenças entre humanos e não humanos pode levar à não aplicabilidade dos resultados a estes. Nesse ponto, os enunciadores apropriam-se do discurso do outro por meio de uma citação indireta - "Alguns defensores mais radicais dos direitos dos animais argumentam que, como estes são diferentes do ser humano, nada do que se estuda neles ajuda a entender a nossa espécie" (ALVES; COLLI, 2006, p. 26) -, para afirmar que tal discurso não tem validade, uma vez que as reações químicas que ocorrem nas células são semelhantes em todos os organismos. Dessa forma, ao mencionar um dos argumentos utilizados pelos defensores dos direitos animais e negar tal argumento, os enunciadores constroem sua visão sobre o tema e realizam a progressão temática do artigo: os resultados dos testes realizados em animais são extensíveis aos seres humanos porque todos os organismos funcionam de maneira muito similar. Logo, percebemos o posicionamento ideológico dos enunciadores: os defensores dos direitos animais estão equivocados. Por essa razão, os enunciadores mencionam o argumento da semelhança a fim de convencer o leitor acerca da falácia presente na reflexão dos defensores dos direitos animais. 
Em seguida, os enunciadores do artigo analisado afirmam que os experimentos realizados em animais permitiram o diagnóstico e o tratamento de diversas doenças humanas.

\begin{abstract}
Para entender o funcionamento de um órgão ou tecido, os antigos fisiologistas, como Bernard, o retiravam de um animal e observavam os efeitos de sua ausência. Essa técnica pioneira, embora causasse sofrimento, permitiu que esses pesquisadores fizessem muitas descobertas sobre as funções dos órgãos, levando a avanços no conhecimento preciso de suas funções e no diagnóstico e no tratamento de diversas doenças humanas. Afinal, em todos os vertebrados humanos ou não - os rins filtram o sangue e formam urina, o estômago digere os alimentos, o pâncreas produz enzimas digestivas e assim por diante. Não podemos nos esquecer que todos eles descendem de um tronco evolutivo comum. (ALVES; COLLI, 2006, p. 26)
\end{abstract}

Esse recorte também auxilia a compreender o posicionamento ideológico dos enunciadores, que acreditam que, ainda que os experimentos em animais causem sofrimento a estes, são indispensáveis por permitirem inúmeros avanços no conhecimento científico. Além disso, realizam a progressão temática do artigo ao afirmarem, agora, uma semelhança entre os vertebrados. No recorte anterior, mencionam que todos os seres são semelhantes, especificando e restringindo tal semelhança aos vertebrados apenas. Essa informação é importante para a construção temática, pois auxilia a direcionar a discussão aos seres diretamente envolvidos e afetados pela prática da experimentação laboratorial: os vertebrados, ou seja, os que são testados, como ratos, coelhos e macacos, e os que são beneficiados com esses testes - os humanos.

Salientamos, contudo, que os sistemas citados não são dotados de igualdade completa. Apenas para exemplificar, os rins diferem bastante entre os vertebrados, podendo ser pronefros (cefálicos e retiram excretas do celoma), mesonefros (torácicos e retiram excretas do celoma e do sangue) e metanefros (abdominais e retiram excretas do sangue), diferenças que precisam ser levadas em consideração e ocasionam resultados distintos quando da execução de experimentos que envolvem este órgão. Logo, a asserção dos enunciadores, de que "em todos os vertebrados - humanos ou não - os rins filtram o sangue e formam urina, o estômago digere os alimentos, o pâncreas produz enzimas digestivas e assim por diante" (ALVES; COLLI, 2006, p. 26), serve ao propósito de sustentar o posicionamento ideológico de que a igualdade entre os vertebrados seria motivo suficiente para garantir a extensibilidade dos resultados em testes científicos aos seres humanos. O que podemos perceber com o exemplo acerca do modo de funcionamento dos rins é que não há igualdade, mas apenas uma semelhança fisiológica, que precisa ser relativizada e avaliada com cautela para afirmar se seria ou não possível realizar testes em uma espécie de vertebrado e aplicar os resultados a outra espécie.

Em seguida, os enunciadores discorrem sobre o auxílio que as cobaias prestaram ao desenvolvimento da medicina.

Os animais também ajudaram e ajudam a medicina de outras maneiras. Eles são utilizados, por exemplo, para a experimentação de medicamentos ou procedimentos antes de sua aplicação em seres humanos. Isso foi fundamental na pesquisa e no desenvolvimento de medicamentos como anestésicos, antibióticos, anticoagulantes, insulina e drogas para controlar a pressão sanguínea ou a rejeição em transplantes, entre outros. A experimentação prévia em animais 
também é relevante nos casos de muitos medicamentos, de vacinas (para difteria, poliomielite, meningite bacteriana e outras); de procedimentos como os próprios transplantes, a transfusão de sangue, a diálise renal e a substituição de válvulas cardíacas; e, finalmente, de tratamentos para asma, leucemia e outras doenças. (ALVES; COLLI, 2006, p. 26)

Nesse recorte, são citados pelos enunciadores exemplos práticos, ligados ao cotidiano do leitor, acerca do que a experimentação laboratorial com animais permitiu desenvolver. Tais menções ocupam a função de sensibilizar o leitor acerca da importância dos testes em animais para o seu próprio cotidiano. Tendo em vista a quantidade de medicamentos e procedimentos citados, é praticamente impossível que o leitor não se identifique com a utilização/dependência de algum destes, levando-o a entender a necessidade de tais testes.

Os enunciadores finalizam, então, esta que é a primeira seção do artigo com algumas perguntas.

Seria possível, por exemplo, repor um gene defeituoso de um indivíduo e com isso curar um defeito genético, tornando realidade a terapia gênica? Ou então: o que causa as doenças degenerativas - como a de Alzheimer - e como curá-las? Essas perguntas levam a outra: como fazer experimentos que permitam responder a essas questões sem a utilização de animais? (ALVES; COLLI, 2006, p. 26)

Esse recorte auxilia a reforçar o argumento de que os testes em animais são importantes para a descoberta da cura ou do tratamento para doenças, corroborando para a progressão temática do artigo ao apresentar outra faceta da experimentação animal: a dos avanços que ainda precisam ocorrer na ciência para que a medicina avance em aspectos ainda não resolvidos. Além disso, a pergunta de "como fazer experimentos que permitam responder a essas questões sem a utilização de animais?" (ALVES; COLLI, 2006, p. 26) cumpre ainda outras funções no artigo: a de levar o leitor à leitura da seção seguinte na expectativa de que tal questionamento possa ser respondido e de mostrar que a ciência ainda tem muitas dúvidas ainda para sanar.

A resposta à última pergunta do recorte anterior vem implícita no subtítulo da seção seguinte: "Uso é necessário, mas com ética" (ALVES; COLLI, 2006, p. 27). Esse subtítulo é explicado pelos enunciadores no primeiro parágrafo da seção em questão.

Em alguns casos, o progresso científico conseguiu substituir, nos experimentos, o uso de animais vivos por culturas de células mantidas em laboratório ou por modelos matemáticos e computacionais. No entanto, ainda estamos longe de poder prescindir dos animais para uma série de experimentos ou para a fabricação de reagentes. Ainda não é possível, por exemplo, obter o soro que salva a vida de numerosas pessoas picadas por cobras venenosas sem os cavalos, que produzem quando recebem doses diluídas do veneno - os anticorpos contra esse veneno. E como manter as cobras para obter o veneno e preparar o soro sem lhes dar camundongos para comer, já que só se alimentam de seres vivos que elas mesmas caçam? (ALVES; COLLI, 2006, p. 27)

Percebemos, assim, mais uma vez, que o posicionamento ideológico dos enunciadores é de que a realização de testes em animais é fundamental para o progresso da ciência. Sob a perspectiva dos enunciadores, o progresso científico, dependente da 
realização de testes em animais, é o que permite inclusive que alguns experimentos possam ser realizados hoje de outras formas (isto é, sem a utilização de animais), o que reafirma a necessidade de tais testes: permitiram o progresso da ciência, fator que possibilita, por sua vez, a utilização de um menor número de animais em testes ou até mesmo sua substituição por métodos alternativos. Novamente, os enunciadores estabelecem uma relação entre os testes em animais e os seus benefícios para o leitor, afinal esses testes são necessários porque levam à obtenção de soro que "salva a vida de numerosas pessoas picadas por cobras venenosas" (ALVES; COLLI, 2006, p. 27).

A mesma relação aparece no recorte a seguir.

Outro exemplo bem-sucedido de substituição que interessa tanto à espécie humana quanto às outras está na produção da vacina contra a raiva. Essa vacina exigia, para sua fabricação, a multiplicação do vírus no cérebro de camundongos recém-nascidos, mas agora isso é feito em células mantidas em cultura. Assim, eliminou-se não apenas o uso de grandes quantidades de animais, mas também a possibilidade de reações imunológicas que levavam à destruição da mielina (membrana que reveste parte dos neurônios) em seres humanos que recebiam a vacina. Graças a esse novo método de produção e a outros procedimentos, o Instituto Butantan, por exemplo, reduziu pela metade o uso de animais. Essa e outras alternativas vêm sendo desenvolvidas em função dos esforços feitos em todas as instituições de pesquisa biomédica. (ALVES; COLLI, 2006, p. 29)

Esse recorte demonstra novamente o posicionamento ideológico dos enunciadores no que diz respeito à necessidade da utilização de animais em testes científicos. Além disso, evidencia a crença dos enunciadores de que mesmo a diminuição do emprego de animais em experimentos só é possível devido aos esforços dos cientistas para isso, uma vez que estes estariam preocupados com essa questão.

Apesar de tal preocupação, conforme os enunciadores do artigo ora analisado, é preciso avaliar se o sacrifício de algumas vidas para salvar outras será válido.

Além da preocupação ética com os experimentos atuais, cientistas de todo o mundo esforçam-se para investigar métodos que permitam diminuir a quantidade de animais usados e substituí-los, particularmente nos casos em que é preciso submetê-los a processos dolorosos ou a substâncias tóxicas. É necessário sempre avaliar se os custos, em termos de possível sofrimento do animal utilizado, serão compensados pelos potenciais benefícios da pesquisa (ALVES; COLLI, 2006, p. 28)

Nesse recorte, podemos perceber que o posicionamento ideológico dos enunciadores parte da premissa de que, no caso da experimentação animal, os fins justificam os meios, ou seja, é aceitável sacrificar algumas vidas se outras forem beneficiadas com tal sacrifício. Além disso, governando esse sacrifício está o progresso da ciência, uma vez que, de acordo com os enunciadores, para que todos os avanços obtidos a partir da ciência continuem ocorrendo, é imprescindível o uso de animais.

Os enunciadores afirmam, também, que

em suma, é temerário atestar a inocuidade de um preparado a ser usado em seres humanos sem primeiro prová-lo em camundongos ou ratos 
(eventualmente em coelhos) especialmente criados para essa finalidade. O emprego de animais em numerosos experimentos e outros procedimentos científicos é essencial, mas isso não é feito de qualquer maneira. Os debates em torno do sofrimento dos animais levaram há muito tempo a leis que determinavam como deveriam ser tratados, inclusive por cientistas. (ALVES; COLLI, 2006, p. 27)

Podemos perceber a reiteração do posicionamento ideológico dos enunciadores acerca da validade de sacrificar vidas de determinadas espécies em prol de outra espécie, já que seria, conforme os enunciadores, "temerário atestar a inocuidade de um preparado a ser usado em seres humanos sem primeiro prová-lo em camundongos ou ratos (eventualmente em coelhos)" (ALVES; COLLI, 2006, p. 27). Notamos, assim, que a espécie humana ocupa papel central na discussão proposta pelos enunciadores sobre a experimentação com animais.

É possível observar, ainda, uma distinção de valor entre os próprios animais não humanos como parte da posição ideológica dos enunciadores. Nesse sentido, conforme o recorte anterior, as cobaias mais utilizadas são camundongos e ratos, que podemos entender como de menor valor, e apenas eventualmente são empregados coelhos, espécie que têm maior valor. Estes são citados entre parênteses e acompanhados do adjetivo "eventualmente". Sabemos, contudo, que no Brasil coelhos são amplamente utilizados, em mesmo número que roedores talvez, devido ao crescimento da indústria de cosméticos.

Tal cisão valorativa entre as espécies está no cerne do posicionamento ideológico dos enunciadores e está presente também quando estes afirmam que um dos princípios da experimentação animal consiste em "utilizar o mínimo de animais necessário para se obter resultados válidos e preferir espécies menos "evoluídas" (ALVES; COLLI, 2006, p. 28). A expressão "menos evoluídas", empregada pelos enunciadores, denota que, para estes, existem espécies mais evoluídas, cuja referência consistiria em nossa própria espécie. Sendo assim, podemos entender essa expressão como significando justamente um maior distanciamento em relação à espécie humana, pois não existem, conforme Darwin (2003), espécies mais ou menos evoluídas ${ }^{8}$.

A distinção entre o valor concedido à vida dependendo da espécie a que o ser pertence é reafirmada pelos enunciadores no seguinte recorte.

Portanto, o uso de animais em projetos de pesquisa deve ser uma alternativa ao uso de seres humanos e ser indispensável, imperativo ou requerido. É fundamental ainda que as instituições mantenham comissões de ética operantes que avaliem a necessidade de uso de animais e que vigiem como o animal está sendo mantido e manipulado durante e após o término do experimento. Essas comissões existem hoje

\footnotetext{
${ }^{8}$ Conforme a teoria da seleção natural, proposta por Darwin (2003) na obra $A$ origem das espécies, essa igualdade se deve ao fato de que o objetivo primevo das espécies é se adaptar ao meio ambiente a fim de se reproduzir e, com isso, passar seus genes às próximas gerações (DARWIN, 2003; DAWKINS, 1979). Desse modo, todas as espécies, embora possam ser mais complexas ou mais derivadas, por terem passado por mais modificações estruturais com o passar do tempo, apresentam o mesmo grau evolutivo, já que todas, de um modo ou de outro, estão adaptadas ao meio em que vivem. Logo, do ponto de vista evolutivo, os seres humanos não seriam superiores ou mais evoluídos que as demais espécies e, consequentemente, não poderiam fazer uso destas conforme ocorre em nossa sociedade, pelo menos não segundo esse pressuposto.
} 
nas universidades e centros de pesquisa, inclusive no Brasil. (ALVES; COLLI, 2006, p. 28)

Nesse recorte, evidencia-se novamente que o uso de animais em testes evita o uso de seres humanos, ou seja, serve para substituir os humanos em testes. Além disso, os enunciadores entendem que há comissões especializadas em determinar a necessidade ou não da realização de tais experimentos. Assim, até o momento, é possível depreender que os enunciadores percebem a experimentação animal como imprescindível ao progresso da ciência, o que está embasado tanto na premissa de que os fins justificam os meios quanto na premissa de que as espécies têm valor distintos, e que tal prática é a responsável pela existência de inúmeros medicamentos dos quais a população faz uso.

Os enunciadores citam, então, o sacrifício de cobaias realizado com frequência após o término dos experimentos, afirmando que a maneira

mais aceita é a utilização de câmaras onde se injeta gás carbônico lentamente, provocando a morte do animal apenas quando ele já está inconsciente. Esse modo de agir é considerado mais compassivo. No entanto, especialistas têm questionado o método, alegando que não há garantia de que o animal não sofra. [...] Outros defendem o uso do gás argônio, comum no sacrifício de aves domésticas em abatedouros. $\mathrm{O}$ problema é complexo, até porque envolve o sofrimento psicológico do técnico ou do cientista que, mesmo escolhendo o método que lhe pareça menos causador de sofrimento, tem de sacrificar o animal. (ALVES; COLLI, 2006, p. 29)

Nesse recorte, os enunciadores deixam em aberto a questão sobre a existência ou não de sofrimento nos animais submetidos a testes ao serem sacrificados. Instauram, assim, uma dúvida a esse respeito, afirmando que, embora haja um esforço para evitar o sofrimento, os especialistas no assunto não têm certeza se os animais, de fato, não sofrem. Os enunciadores admitem, assim, que os experimentos realizados podem ocasionar dor tanto durante sua execução quando durante seu término, quando as cobaias são descartadas e mortas.

Em seguida, os enunciadores fazem referência à utilização do gás argônio, comum em abatedouros, questão já levantada em ambos os artigos analisados ao citarem o pensamento de Claude Bernard, de que, se os animais são utilizados em outras esferas da vida humana, também podem ser utilizados na ciência.

Nós temos o direito de fazer experimentos animais e vivissecção? Eu penso que temos este direito, total e absolutamente. Seria estranho se reconhecêssemos o direito de usar os animais para serviços caseiros, para comida, e proibir o seu uso para a instrução em uma das ciências mais úteis para a humanidade. (BERNARD, 1865 apud RAYMUNDO; GOLDIM, 2002, p. 39)

Eu penso que temos esse direito, total e absolutamente. Seria estranho se reconhecêssemos o direito de usar os animais para serviços caseiros e alimentação, mas proibíssemos seu uso para o ensino de uma das ciências mais úteis para a humanidade. Experimentos devem ser feitos tanto no homem quanto nos animais. Os resultados obtidos em animais podem ser todos conclusivos para o homem, quando sabemos como experimentar adequadamente. (BERNARD apud ALVES; COLLI, 2006, p. 26) 
Dessa perspectiva, se o gás argônio é utilizado para matar aves destinadas à alimentação, também pode ser empregado para ocasionar a morte de cobaias. Por fim, os enunciadores do artigo de divulgação afirmam que a questão do abate é complexa porque implica sofrimento ao pesquisador, argumento também apresentado no artigo científico quando o assunto era a ação de ativistas (que poderia, segundo os enunciadores do artigo analisado, ocasionar danos diretos aos pesquisadores). Os enunciadores do artigo de divulgação partem, assim, da perspectiva de que a prática da experimentação animal causa sofrimento psíquico aos cientistas, desculpando o pesquisador pelos possíveis danos causados aos animais, como o sofrimento e a morte, por exemplo, e vitimando-o em função do sofrimento a que também é submetido.

Essa posição ideológica parece antecipar a principal questão abordada da última seção no artigo, intitulada Não há prazer em maltratar, em que os enunciadores explicitam que

até há pouco tempo o cientista era visto como um benfeitor da humanidade. No entanto, no presente, ele é muitas vezes apontado como um profissional frio e calculista, sem sentimentos. Grupos que assim pensam estão equivocados, já que nenhum cientista, em sã consciência, teria prazer em maltratar animais. (ALVES; COLLI, 2006, p. 29)

Sob a perspectiva dos enunciadores, conforme esse recorte, o cientista é desculpado de seus atos, pois não sente prazer naquilo que faz, mas realiza experimentos que causam sofrimento em animais porque estes são necessários ao progresso da ciência. Diante disso, os enunciadores afirmam, por fim, que

essa visão negativa [acerca dos cientistas e da experimentação animal], porém, dificilmente será revertida apenas com opiniões ou artigos como este. É necessário que os cientistas, através de suas instituições representativas, como as sociedades científicas e as academias de ciências, promovam campanhas de esclarecimento, divulgando a ciência e seus métodos, para não perder o apoio da opinião pública para uma atividade essencial ao progresso e que, como tal, deve ter o reconhecimento da sociedade. (ALVES; COLLI, 2006, p. 29)

Esse recorte evidencia um dos intentos das atividades de divulgação científica: divulgar a importância do progresso obtido na ciência para o cotidiano da população a fim de obter reconhecimento e apoio desta às ações executadas. Isso inclui, no caso em questão, a aceitação do uso de animais em testes científicos, já que estes, embora causem sofrimento aos animais, são essenciais ao progresso científico, permitindo $o$ desenvolvimento de produtos extremamente úteis, como vacinas e medicamentos.

\section{ALGUMAS CONSIDERAÇÕES}

Os dois artigos analisados apresentam um mesmo posicionamento sobre o tema a que se referem: são favoráveis à experimentação em animais não humanos em prol do progresso da ciência. Um aspecto inicial que chama atenção consiste na implementação, no artigo de divulgação científica, de imagens ilustrativas do que seria o uso de animais em experimentos. Tais imagens, contudo, mostram animais em estado normal, sem apresentar nenhum efeito mais drástico e, ao mesmo tempo, mais comum dos testes realizados. A imagem que mais se aproxima dos efeitos conhecidos dos testes em animais 
consiste na foto de capa, em que um coelho com uma mancha amarelada no topo da cabeça é ilustrado. Fenômenos como inflamações nos olhos, crateras na pele devido à aplicação constante de substâncias agressivas, agulhas e outros equipamentos acoplados ao cérebro, ausência de órgãos e partes do corpo abertas são aspectos comuns na execução desses testes. Percebemos, dessa forma, um elemento atrativo ao leitor, mas que, assim como o restante do artigo, busca amenizar a visão do leitor acerca das implicações que os testes realizados ocasionam a fim de legitimar tal prática. Notamos, assim, que as imagens presentes no artigo também evidenciam o posicionamento dos enunciadores sobre a temática da experimentação animal, uma vez que optam por não evidenciar ao leitor nenhum efeito visível da experimentação.

Conforme a análise dos artigos e das posições defendidas pelos enunciadores, podemos afirmar que o uso de imagens que não sejam chocantes (mas também pouco representativas da realidade) é feito porque o emprego de animais em estudos científicos ainda é indispensável em muitos casos, conclusão que a chegam os enunciadores dos dois artigos analisados. Para chegar a tal conclusão, ambos os artigos apresentam julgamentos de valor que acabam denunciando seus posicionamentos ideológicos acerca da temática. No artigo científico, isso aparece no seguinte recorte.

Durante a década de 80, o movimento para eliminar o uso de animais em pesquisas biomédicas cresceu assustadoramente, principalmente nos Estados Unidos, Inglaterra, Canadá e Austrália. Alguns grupos radicais na defesa dos direitos dos animais praticaram atentados contra laboratórios, biotérios, instalações universitárias e até mesmo contra residências e carros de pesquisadores. Somente nos Estados Unidos, de 1980 a 1989, tais grupos protagonizaram mais de 29 ataques a instituições americanas de pesquisa, roubando mais de 2.000 animais, resultando num prejuízo de mais de 7 milhões de dólares em danos físicos e arruinando anos de pesquisas científicas em andamento. (ALVES; COLLI, 2006, p. 34; grifos nossos)

Já no artigo de divulgação, é preciso realizar uma leitura mais atenta para reconhecer as expressões que denotam o posicionamento presente.
Alguns defensores mais radicais dos direitos dos animais argumentam que, como estes são diferentes do ser humano, nada do que se estuda neles ajuda a entender a nossa espécie. Nada mais falso, já que todas as células vivem em conseqüência de um concerto de reações químicas muito semelhantes em todos os organismos - desde os mais simples até o Homo sapiens. (RAYMUNDO; GOLDIM, p. 26; grifos nossos)

Ambos os recortes denotam um mesmo posicionamento dos enunciadores perante o tema da experimentação em animais. Para quem entende a ciência e seu progresso como um fim genuíno que justifica o sacrifício de seres vivos de espécies diferentes da humana, aqueles que lutam contra a experimentação animal são vistos como radicais e seus atos entendidos como prejudiciais ao desenvolvimento científico. Tal posicionamento justifica e explica a presença de expressões como "atentados", "grupos radicais", "roubando" e "arruinando", por exemplo.

O mesmo processo ocorre com o que podemos denominar neste estudo de apelo ao leitor. Ele existe nos dois artigos analisados de formas diferentes. Enquanto que, no artigo de divulgação, são citados os inúmeros benefícios da experimentação animal, todos ligados à criação de medicamentos populares, como soros e vacinas, elementos presentes 
no cotidiano da população, no artigo científico isso é feito por meio de uma referência ao nazismo, ficando os avanços proporcionados pela experimentação menos explícitos. Neste caso, é lícito supor que, por se tratar de um público leitor pertencente à própria comunidade científica e, portanto, conhecedor dos diversos resultados da experimentação animal, não seria necessário citar tais avanços. Sendo assim, parte-se para uma memória cultural, retomada para lembrar que, no nazismo alemão, Hitler desprezava o ser humano e amava seu cachorro, permitindo que a experimentação ocorresse em humanos. Além disso, conforme os enunciadores desse artigo, seria moralmente errado, ou pelo menos duvidoso, amar mais seres de outras espécies que os de nossa espécie, o que fica implícito na citação de Hitler - "Quanto mais eu conheço a espécie humana, mais eu gosto do meu cachorro" (RAYMUNDO; GOLDIM, p. 33) - acompanhada das seguintes perguntas: "pode alguém amar mais a um animal que a um ser humano? Pode alguém amar mais a doença que a saúde? Pode alguém amar mais a ignorância que o conhecimento do corpo?" (RAYMUNDO; GOLDIM, p. 33). Tais questionamentos não são respondidos diretamente no artigo, embora sua própria presença, bem como a condução dos outros argumentos selecionados ao longo do artigo, evidencie o posicionamento dos enunciadores a seu respeito.

No artigo de divulgação científica, perguntas também são realizadas, mas estas não são, em sua maioria, respondidas, porque cabe aos cientistas, por meio da experimentação animal, respondê-las.

Esses animais ajudam a responder às perguntas básicas: a superexpressão ou a ausência de um gene afetam o quê? Além destas, há muitas outras perguntas importantes. Seria possível, por exemplo, repor um gene defeituoso de um indivíduo e com isso curar um defeito genético, tornando realidade a terapia gênica? Ou então: o que causa as doenças degenerativas - como a de Alzheimer - e como curá-las? Essas perguntas levam a outra: como fazer experimentos que permitam responder a essas questões sem a utilização de animais? (ALVES; COLLI, 2006, p. 26)

A partir das análises, percebemos que a única pergunta respondida pelos enunciadores do artigo de divulgação é a seguinte: "como fazer experimentos que permitam responder a essas questões sem a utilização de animais?" (ALVES; COLLI, 2006, p. 26). A resposta está implícita no subtítulo que inicia a seção seguinte: Uso é necessário. Ou seja, não há como obter tais respostas sem a utilização desses animais, até mesmo porque inclusive a diminuição do número de cobaias empregado nesses testes só foi possível com o progresso da ciência, ocasionado pelo próprio uso de animais em laboratórios.

Esse progresso é citado de forma recorrente no artigo de divulgação, assim como a defesa do trabalho do cientista. Tais questões podem ser evidenciadas, conforme os enunciadores desse artigo, pelos inúmeros avanços obtidos, os quais estão presentes no cotidiano das pessoas e, muitas vezes, salvam diversas vidas. Tal progresso é evidenciado, ainda, por meio de uma referência quase que constante ao presente em relação ao passado. Apresentam-se, assim, as incontáveis mudanças que a ciência ocasionou na vida das pessoas, bem como em seu próprio modo de fazer pesquisa.

Cabe mencionar, ainda, que o discurso de divulgação científica ora analisado, em certa medida, referenda o status quo do modo de produção científico. Para isso, alude ao progresso da ciência e à importância do trabalho do cientista para a sociedade e, 
consequentemente, à necessidade de respeito a esse trabalho por parte da população, bem como à utilização de imagens ilustrativas bastante conciliatórias acerca do que seriam os experimentos realizados nessas cobaias.

A partir disso, podemos afirmar que os interesses que movem o gênero de discurso científico não são tão distintos assim daqueles que movem o gênero científico: quer-se o produto do labor científico independentemente dos recursos (sacrifício e sofrimento animal) que sejam necessários para isso. A possibilidade de substituir o uso de animais por métodos alternativos exigiria uma reestruturação no modo de fazer ciência, o que, seja por aspectos econômicos, seja por alienação, acaba por não ocorrer ou acontece a passos lentos.

A partir das análises, podemos perceber que, sob a perspectiva dos enunciadores dos artigos, o sofrimento ou a morte animal leva a avanços na ciência, como a criação de medicamentos que salvam vidas humanas. Recorre-se, assim, à citação de "produtos" dos testes em animais que são do conhecimento do leitor por estarem presentes em seu cotidiano, mas não se estabelece em nenhum momento a discussão acerca do direito que o ser humano arroga a si mesmo de sacrificar vidas de seres de outras espécies em benefício de sua.

Tal negligência pode ser explicada pela afirmação dos enunciadores de ambos os artigos de que, para todos esses avanços ocorrerem, é imprescindível o uso de animais. Se tal debate fosse, contudo, realizado de outra forma, isto é, se abordasse o direito ou não de utilizar animais não humanos em experimentos, independente das consequências disso, e se chegássemos ao consenso de que tal direito não existe (falamos em consenso porque muitos pesquisadores do tema já demonstraram a validade de tal perspectiva), seria necessário abandonar o status quo do atual modo de produzir ciência. Assim, perguntas como "Se não fosse possível utilizá-los, como saber se as vacinas produzidas para imunizar as crianças contêm certas substâncias tóxicas?" (ALVES; COLLI, 2006, p. 27) teriam de ser substituídas por outras, tais como: de que modo desenvolver uma ciência que respeite o direito à vida? Dessa forma, a premissa de que os fins justificam os meios (sacrificar vidas em detrimento de outras) e de que o progresso deve ser alcançado a qualquer custo teria de ser revista. Enquanto tal mudança de perspectiva não for feita, o pressuposto de que algumas vidas valem mais que outras continuará sendo utilizado e aceito pela população.

Esse pressuposto da valoração da vida conforme a espécie à que pertence é um dos pilares da forma como nos relacionamos com os animais não humanos: o especismo. O termo "especismo" foi proposto em 1970 pelo psicólogo britânico Richard Ryder e popularizado pelo filósofo australiano Peter Singer (BRÜGGER, 2009, p. 2002). Conforme Peter Singer, em sua obra Ética prática,

o especismo pode ser definido como qualquer forma de discriminação praticada pelos seres humanos contra outras espécies. Como o racismo ou o sexismo, o especismo é uma forma de preconceito que se baseia em aparências externas, físicas etc. A simples constatação de uma diferença é usada como um pretexto ou motivo para a não aplicação do princípio ético da igualdade, entendida como igual consideração de interesses. Mas os pretextos que supostamente justificariam essa discriminação não procedem. Na ética utilitarista, ser passível de sofrimento é a característica que diferencia os seres que têm interesses - os quais deveríamos considerar - dos que não os têm. A condição de "senciente" (capacidade de sofrer ou experimentar prazer ou felicidade) 
é, portanto, suficiente para que um ser vivo seja considerado dentro da esfera da igual consideração de interesses. A crítica ao especismo é especialmente elucidativa para repensarmos atitudes nossas tão arraigadas como saborear a carne de um animal, um interesse muito pequeno quando comparado à vontade de viver daquele animal. (SINGER, 1998, p. 25)

Outra definição possível para o especismo é a apresentada por Garry L. Francione, teórico estadunidense e professor de direito e filosofia, na obra Introduction to animal rights. Para Francione (2000), o especismo fundamenta-se no pertencimento à espécie humana como argumento para justificar o estatuto de propriedade dos animais não humanos, instaurando, conforme observa Trindade (2013), um elemento novo a essa noção: o paradigma legal no qual o especismo está assentado. Dessa forma, o especismo não está desvinculado da ação de usar um indivíduo, no sentido de condicioná-lo ao estatuto de mero recurso econômico.

Francione (2000) afirma que especismo, racismo e sexismo são comportamentos similares, pois se assentam na premissa de que certas características biológicas determinam se um ser pode ser alvo de igual consideração moral ou não. De acordo com Trindade (2013), a escravidão humana e a exploração animal são semelhantes, pois humanos e não humanos em tais condições têm o seu interesse de não sofrer violado sob a justificativa de que, por meio da adoção de características fisiológicas arbitrárias (como espécie e raça, por exemplo), é possível definir sobre quem terá o seu interesse em não sofrer considerado como importante.

O especismo pode ser entendido, assim, como análogo ao racismo. Neste sistema de pensamento, os racistas pressupõem que pessoas com determinadas características fisiológicas diferentes das suas têm menor valor. No especismo, ocorre algo que segue o mesmo princípio: supõe-se que os fatores biológicos que diferenciam a espécie humana das outras originam um valor moral que as outras espécies não teriam. Acredita-se, dessa forma, que a espécie humana, por ser dotada de uma suposta superioridade, tem o direito de se apropriar de outras espécies a seu bel-prazer. Logo, se o uso de animais não humanos é aceito, devido à sua inferioridade em relação aos humanos, o sofrimento a que as cobaias são submetidas nos laboratórios, por exemplo, torna-se irrelevante - ou pelo menos não consiste em um motivo para que tais práticas não ocorram, como foi possível perceber nos artigos - científico e de divulgação científica - analisados neste estudo.

Precisamos levar em conta, entretanto, que, de acordo com Francione (2008), os animais empregados em experimentos científicos, assim como os humanos, são seres sencientes, ou seja, possuem uma consciência acerca de si mesmos e, portanto, preferem uma coisa em detrimento de outra. Justamente por serem dotados de senciência, os animais não humanos deveriam ser tratados sob a perspectiva da igual consideração de interesses, o que significa que o interesse de continuar vivo ou de não sofrer tem o mesmo valor para indivíduos sencientes, sejam eles humanos ou não. Contudo, com exceção de países como Nova Zelândia e França, que recentemente reconheceram os animais como seres sencientes e, portanto, sujeitos de direito, nos demais locais do globo, os animais ainda são vistos como coisas e, consequentemente, como propriedade. Não há, assim, um reconhecimento da vontade de viver como intrínseca a esses seres.

Essa premissa pode ser facilmente visualizada, por exemplo, na própria designação do homem como ser humano e de todos os outros animais como apenas animais (o homem também é um animal). Instaura-se, assim, uma barreira também 
linguística entre uma espécie e todas as outras, ignorando os próprios princípios da classificação das espécies proposta por Darwin e aceita como paradigma na comunidade científica. Conforme observa Ryder,

a partir de Darwin, os cientistas passaram a concordar que não há uma diferença essencial "mágica" entre humanos e outros animais, biologicamente falando. Por que, então, fazemos essa distinção moral quase absoluta? Se todos os organismos estão em um contínuo físico, então nós também devemos estar no mesmo contínuo moral. (2011, p. 50 ; grifos do autor)

As considerações de Ryder (2011), criador do termo especismo, instigam outros questionamentos ainda. Se todos os seres são igualmente evoluídos da perspectiva científica, o que faz com que o ser humano arrogue a si certa superioridade que emprega como justificativa para se utilizar de animais de outras espécies conforme julgar conveniente? Essa superioridade está de acordo com os paradigmas evolutivos ou apenas facilita o alcance de determinados interesses, possibilitando uma economia de ordem temporal e financeira, por exemplo?

\section{REFERÊNCIAS}

ALVES, Maria Júlia Manso; COLLI, Walter. Experimentação com animais: uma polêmica sobre o trabalho científico. Ciência hoje, v. 39, n. 231, 24-29, out. 2006.

BAKHTIN, Mikhail Mikhailoch. Estética da criação verbal. $5^{\text {a }}$ ed. Tradução do russo: Paulo Bezerra. São Paulo: Editora Martins Fontes, 2010.

. Marxismo e Filosofia da Linguagem: problemas fundamentais do método sociológico da linguagem. Problemas fundamentais do Método Sociológico na ciência da Linguagem. Tradução de Michel Lahud e Yara Frateschi Vieira. 13ª ed. São Paulo, Hucitec, 2009.

BRÜGGER, Paula. Nós e os outros animais: especismo, veganismo e educação ambiental. Linhas críticas, Brasília, v. 15, n. 29, 197-214, jul./dez. 2009.

DARWIN, Charles. A origem das espécies. São Paulo: Hemus, 2003.

DAWKINS, Richard. O gene egoísta. São Paulo: Itatiaia, 1979.

FRANCIONE, G.L. Animals as persons: essays on the abolition of animal exploitation. New York: Columbia University Press, 2008. Press, 2000.

Introduction to animal rights: your child or the dog? Philadelphia: Temple University

GOULD, Stephen Jay. A falsa medida do homem. São Paulo: Martins Fontes, 1991.

KOTTOW, Miguel. História da ética em pesquisa com seres humanos. Revista Eletrônica de Comunicação, Informação \& Inovação em Saúde, Rio de Janeiro, v. 2, p. 7-18, 2008.

MARRAS, Stélio. Ratos e homens e o efeito placebo: um reencontro da cultura no caminho da natureza. Campos, Paraná, v. 2, 117-33, 2002.

RAYMUNDO, Marcia Mocellin; GOLDIM, José Roberto. Ética na pesquisa em modelos animais. Revista Bioética, Brasília, v. 1, n. 10, 2002.

RYDER, Richard Dudley. Speciesism, painism and happiness: a morality for the twenty-first century. Exeter: Imprint Academic, 2011.

SINGER, P. Ética prática. 2a . ed. Trad. Bras. São Paulo: Martins Fontes, 1998.

TRINDADE, Gabriel Garmendia da. Animais como pessoas: a abordagem abolicionista de Gary

L. Francione. Dissertação. Mestrado em Filosofia, Universidade Federal de Santa Maria, 2013. 
Artigo recebido em: maio de 2018.

Aprovado e revisado em: setembro de 2018.

Publicado em: dezembro de 2018.

\section{Para citar este texto:}

SEIDEL, Verônica Franciele; SILVA, Charlies Uilian de Campos Silva. A divulgação da ciência sobre os animais não humanos: o caso dos experimentos científicos. Entremeios [Revista de Estudos do Discurso, ISSN 2179-3514, on-line, www.entremeios.inf.br], Seção Estudos, Programa de Pós-Graduação em Ciências da Linguagem (PPGCL), Universidade do Vale do Sapucaí (UNIVÁS), Pouso Alegre (MG), vol. 17, p. 103-129, jul. - dez. 2018.

DOI: http://dx.doi.org/10.20337/ISSN2179-3514revistaENTREMEIOSvol17pagina103a129 